\title{
VEHICLE ATTRIBUTES CONSTRAINING PRESENT ELECTRIC CAR APPLICABILITY \\ IN THE FLEET MARKET
}

JOSEPH R. WAGNER

December 1979

DEPARTMENT OF ENERGY AND ENVIRONMENT

BROOKHAVEN NATIONAL LABORATORY UPTON, NEW YORK 11973 


\section{DISCLAIMER}

This report was prepared as an account of work sponsored by an agency of the United States Government. Neither the United States Government nor any agency Thereof, nor any of their employees, makes any warranty, express or implied, or assumes any legal liability or responsibility for the accuracy, completeness, or usefulness of any information, apparatus, product, or process disclosed, or represents that its use would not infringe privately owned rights. Reference herein to any specific commercial product, process, or service by trade name, trademark, manufacturer, or otherwise does not necessarily constitute or imply its endorsement, recommendation, or favoring by the United States Government or any agency thereof. The views and opinions of authors expressed herein do not necessarily state or reflect those of the United States Government or any agency thereof. 


\section{DISCLAIMER}

Portions of this document may be illegible in electronic image products. Images are produced from the best available original document. 


\title{
VEHICLE ATTRIBUTES CONSTRAINING PRESENT ELECTRIC CAR APPLICABILITY IN THE FLEET MARKET
}

\author{
JOSEPH R. WAGNER
}

December 1979

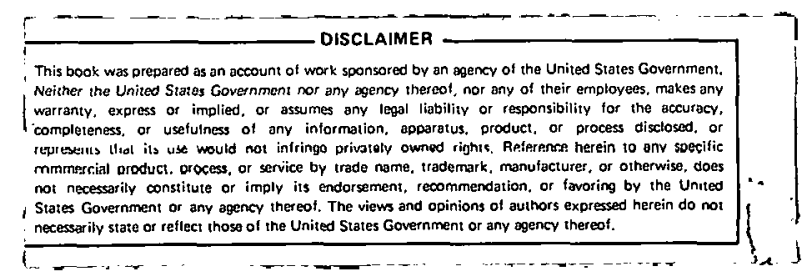

ECONOMIC ANALYSIS DIVISION

NATIONAL CENTER FOR ANALYSIS OF ENERGY SYSTEMS DEPARTMENT OF ENERGY AND ENVIRONMENT BROOKHAVEN NATIONAL LABORATORY ASSOCIATED UNIVERSITIES, INC.

UNDER CONTRACT NO. DE-AC02-76CHOOO16 WITH THE UNITED STATES DEPARTMENT OF ENERGY 


\section{DISCLLAIMER}

This rcport was preparcd as an account of work sponsored by an agency of the United States Government. Neither the United States Government nor any agency thereof, nor any of their employees, nor any of their contractors, subcontractors, or their employees, makes any warranty, express or implied, or assumes any legal liability or responsibility for the accuracy, completeness, or usefulness of any information, apparatus, product, or process disclosed, or represents that its use would not infringe privately owned rights. Reference herein to any specific commercial product, process, or

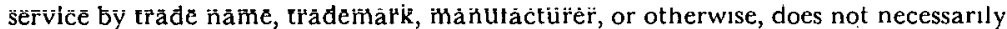
constitute or imply its endorsement, recommendation, or favoring hy the. Inited States Government or any agency, contractor or subcontractor thereof. The views and opinions of authors expressed herein do not necessarily state or reflect those of the United States Government or any agency, contractor or subcontractor thereof.

Printed in the United States of America

Available frum

National Technical Information Service

U.S. Department of Commerce

5285 Port Royal Road

Springfield, VA 22161

Price: Printed Copy $\$ 5.00$; Microfiche $\$ 3.50$ 
One strategy for reducing petroleum imports is to use electric cars in place of conventional vehicles. This paper examines obstacles which electric cars are likely to. encounter in attempting to penetrate a key segment of the passenger car market, namely, the fleet market. A fleet is here defined as a group of cars operated by a corporation or a government agency. The primary data source is a questionnaire that was distributed to fleet operators by the Bobit Publishing Company in the summer of 1977. Six sectors of the fleet market were sampled: police, state and local government, utilities, taxi, rental, and business. The questionnaire was specifically designed to uncover factors limiting market penetration of unconventional vehicles, although no attempt was made to determine price elasticities. Emphasis is on vehicle attributes that are readily quantifiable and relatively projectable, including seating capacity, range, battery recharging characteristics, avallability of power options, and ability to use interstate highways. 


\section{THIS PAGE \\ WAS INTENTIONALLY \\ LEFT BLANK}


Introduction . . . . . . . . . . . . . . . . . . . 1

Research Targets . . . . . . . . . . . . . . . . 2

Survey Instrument. . . . . . . . . . . . . . . . 4

Survey Results and Uses. . . . . . . . . . . . . . . 5

Sumnary. . . . . . . . . . . . . . . . . . . 8

References ......................... 9

Appendix: Bobit Questionnaire . . . . . . . . . . . . . 10

\section{TABLES}

1. United States Passenger Car Registrations and Retail

Sales, Total Versus Fleets With 10 or More Cars. . . . . . . 1

2. Trade-off Parameters and Associated Vehicle Attributes

of Interest to Fleet Operators . . . . . . . . . . . . . 3

3. Targeting Vehicle Attributes on Basis of Ease of Quantification and Ability to Project Relative Attributes of Electric Cars . . . . . . . . . . . 4

4. Response Rate and Car Sampling Rate by Market Sector . . . . . 5

5. Summary of Survey Data . . . . . . . . . . . . . 6

6. Present Status of Electric Car Attributes and Likely Attributes of Mid-1980s Conventional Car . . . . . . . . 7

7. Ranking of Applicability Constraints . . . . . . . . . . 8 
THIS PAGE

\section{WAS INTENTIONALLY \\ LEFT BLANK}




\section{INTRODUCTION}

Since the ofl embargo of 1973-74, numerous proposals have been put forward to reduce petroleum consumption in the United States. Passenger cars have been the target of many of these proposals because they are the largest single user of petroleum, accounting for about 28 percent of all petroleum consumed in the United States. 1 One proposal for reducing oil consumption is to replace present cars with cars propelled by electric storage batteries. The success of this strategy requires (1) the use of electricity produced from nonpetroleum fuels to charge the electric car storage batteries, and (2) capture of a significant share of the automobile market by electric cars. The purpose of this paper is to examine certain physical characteristics of the electric car (EC) which may limit its ability to penetrate a key segment of the market, namely, the fleet market.

A fleet is here defined as a group of passenger cars operated by a corporation or by a government agency. In considering the EC, the fleet market is important for several reasons. It is a large market, typically accounting for 12 percent of new car sales ${ }^{2,3}$ (Table 1). Also, it is likely to differ from the household market in its reaction to changes in vehicle prices, fuel prices, and other variables affecting the desirability of switching from conventional cars to ECs. Most corporations, unlike households, can deduct vehicle costs from their taxable income; therefore, a given cost increase has a smaller impact on their after-tax income. Also, corporations often pass a portion of cost increases on to customers via higher prices. Although these influences are mitigated by competitive pressures, corporations still approach vehicle selection with a perspective different from that of households.

Table 1

United States Passenger Car Registrations and Retail Sales, Total Versus Fleets With 10 or More Cars

\begin{tabular}{|c|c|c|c|c|c|c|}
\hline \multirow{2}{*}{$\begin{array}{c}\text { Calendar } \\
\text { Year }\end{array}$} & \multicolumn{2}{|c|}{$\begin{array}{l}\text { Thousands of } \\
\text { registrations }\end{array}$} & \multirow{2}{*}{$\begin{array}{l}\text { Fleet share } \\
\text { of } \\
\text { registrations, } \%\end{array}$} & \multicolumn{2}{|c|}{$\begin{array}{l}\text { Thousands of } \\
\text { domestic \& } \\
\text { imported } \\
\text { retail sales }\end{array}$} & \multirow{2}{*}{$\begin{array}{l}\text { Fleet share } \\
\text { of } \\
\text { sales, \% }\end{array}$} \\
\hline & Total & Fleet & & Total & Fleet & \\
\hline 1978 & 117147 & 68 & 5.9 & 1131 & 15 & 13 \\
\hline 1977 & 113696 & 6517 & 5.7 & 11185 & 1344 & 12.0 \\
\hline 1973 & 101985 & 5744 & 5.6 & 11439 & 1291 & 11.3 \\
\hline 1970 & 89244 & 5041 & 5.6 & 8405 & 1009 & 12.0 \\
\hline
\end{tabular}


Perhaps the most important reason for examining the fleet market is because of 1 ts value as an EC test market. The U.S. Department of Energy is currently making extensive use of fleets as a proving ground for electric vehicles. ${ }^{4}$ Fleets provide a good test market because of a number of fleet operator characteristics:

1. Managerial and fiscal resources which permit acceptance of some of the risk associated with testing new technology.

2. Bulk buying practices, which enable a fledgling EC manufacturer to concentrate on a limited product line and a small number of customers.

3. Conscientious maintenance and record keeping.

4. The ability to assign certain vehicles to less demanding tasks.

5. Rapid mileage accumulation and high product visibility.

\section{RESEARCH TARGETS}

The market share of a specific vehicle is determined by a large number of vehicle attributes that help define trade-off parameters considered by purchasers when choosing among alternative vehicles. A system of trade-off parameters adapted from the literature is presented in Table 2.5 Shown with each parameter are a number of vehicle attributes of interest to fleet operators.

It is possible to perform a study in which fleet operators specify their relative preferences for various vehicle attributes. Such studies have been made on households, using focus group discussions and conjoint measurement analysis. ${ }^{6}$ The research described in this paper has not yet reached this level of development. The findings are limited to information that could be collected by a first-pass mailed survey of fleet operators. The research plan was to start with simple techniques and to incorporate more complex and comprehensive ones as more is learned about the fleet market.

The use of a mailed survey limited the study to attributes that lend themselves to a questionnaire format. For instance, it is easy to formulate a question regarding the minimum number of seats a fleet opcrator considers acceptable in a vehicle, but is dffficult to formulnte qucations dealing with vehicle attributes such as gradeability (i.e., the speed that can be maintained on a hill of a given steepness), comfort, or crash avoldance. The problem is these attributes are either inherently difficult to quantify, or respondents are not conversant about them.

Although the study was limited in readily quantifiablc factors, the list of attributes was still too long for a single questionnaire. Since the princlpal use of the data would be in making projections, the decision was to concentrate on the attributes whose future values were deemed most predictable. This eliminated cost data because future costs are subject to many unknowns, including government subsidy policies and economies of scale.*

\footnotetext{
*Data on fleet operator trade-offs between price and other vehicle attribuces have become available via a second questionnaire, but the information has not yet been tabulated.
} 
Table 2

Trade-off Parameters and Associated Vehicle

Attributes of Interest to Fleet Operators

\begin{tabular}{|c|c|}
\hline Parameter & Vehicle Attributes \\
\hline Cost & $\begin{array}{l}\text { Life-cycle cost } \\
\text { Purchase price } \\
\text { Depreciation cost } \\
\text { Maintenance cost } \\
\text { Fuel cost } \\
\text { Insurance cost }\end{array}$ \\
\hline Functionality & $\begin{array}{l}\text { Seating capacity } \\
\text { Trunk capacity } \\
\text { Range } \\
\text { Refueling characteristics } \\
\text { Acceleration } \\
\text { Speed } \\
\text { Gradeability } \\
\text { Availability of power options } \\
\text { Reliability } \\
\text { Durability }\end{array}$ \\
\hline Amenity & $\begin{array}{l}\text { Comfort } \\
\text { Styling } \\
\text { Drivability } \\
\text { Image }\end{array}$ \\
\hline Safety & $\begin{array}{l}\text { Crash avoidance } \\
\text { Crashworthiness } \\
\text { Nonoperating safety }\end{array}$ \\
\hline $\begin{array}{l}\text { Social cost } \\
\text { Resource consumption } \\
\text { Emissions } \\
\text { Noise }\end{array}$ & $\begin{array}{l}\text { mpg or } \mathrm{mi} / \mathrm{kWh} \\
\text { Ability to meet federal, state, } \\
\quad \text { and local regulations }\end{array}$ \\
\hline
\end{tabular}

Table 3 shows the results of sorting the attributes according to the above two criteria. Grouping on the basis of ease of quantification and perceived ability to project EC attributes brought together high-priority attributes for inclusion in the first-pass questionnaire. The highestpriority attributes are identifled as primary targets. The lower-priority attributes are identified as secondary or tertiary targets. 
Table 3

Targeting Vehicle Attributes on Basis of Ease of Quantification and Ability to Project Relative Attributes of Electric Cars

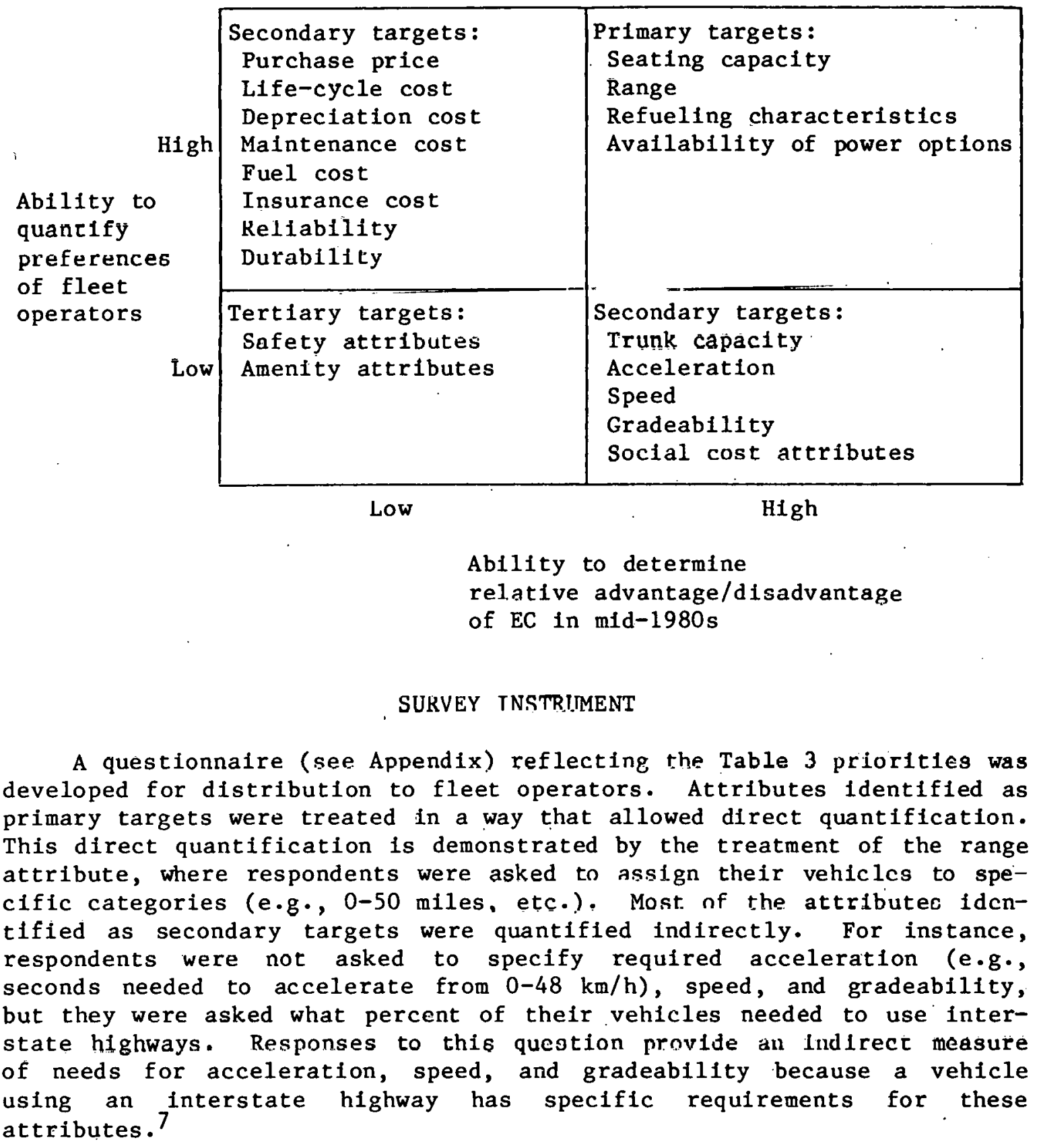


The survey was distributed by the Bobit Publishing Company in August 1977, with a partial resample in January 1978. Recipients were subscribers of Bobit's Automotive Fleet magazine, plus additional persons included to ensure coverage of certain sectors of the fleet market. The sectors were defined to be compatible with existing data available from Bobit. The sample is not a statistically designed probability sample because of the lack of a reliable fleet census containing such variables as the regional location and size distribution of all fleets. Table 4 shows response rates per sector and estimated sampling rates, computed with the aid of published Bobit data. 3

\section{SURVEY RESULTS AND USES}

Complete survey results are available in a report prepared by Brookhaven National Laboratory for the U.S. Department of Energy. 8 Table 5 shows results covering all the attributes selected as primary targets. In general there is great variability among the sectors, though they tend to fall. Into groups; for instance, the government and utility sectors display similarities.

What do the survey data imply for the electric car? The primary value of the data is that they can be used to estimate upper bounds on the market penetration of an EC with given physical attributes. For instance, Table 5 shows that 17 percent of the cars in the survey sample need only two seats, with the remaining cars needing three or more seats to fulfill their vehicle missions. The implication is that any EC having only two seats could obtain at best a 17 percent share of the fleet market. This would hold regardless of its other physical attributes, although it could be argued that this might not be true if the EC were to have some very great advantage over other vehicles in terms of certain

Table 4

Response Rate and Car Sampling Rate by Market Sector

\begin{tabular}{|c|c|c|c|c|c|c|}
\hline $\begin{array}{l}\text { Market } \\
\text { sector }\end{array}$ & $\begin{array}{l}\text { Questionnaires } \\
\text { sent }\end{array}$ & $\begin{array}{l}\text { Responses } \\
\text { recelved }\end{array}$ & $\begin{array}{l}\text { Response } \\
\text { rate,\% }\end{array}$ & $\begin{array}{c}\text { Cars in U.S. } \\
\text { (thousands), } \\
1977^{a}\end{array}$ & $\begin{array}{c}\text { Cars in sample } \\
\text { (thousands) } \\
1977\end{array}$ & $\begin{array}{l}\quad \text { Car } \\
\text { sampling } \\
\text { rate, } \%\end{array}$ \\
\hline Police & 328 & 85 & 26 & 292 & 41 & 14 \\
\hline Government ${ }^{b}$ & 1942 & 94 & 5 & 642 & 37 & 6 \\
\hline Uti11ty & 2360 & 293 & 12 & 518 & 37 & 7 \\
\hline $\operatorname{Tax} 1$ & 752 & 68 & 9 & 202 & 2 & 1 \\
\hline Rental & 1050 & 56 & 5 & 385 & 36 & 9 \\
\hline Business & 6342 & 671 & 11 & 3067 & 130 & 4 \\
\hline Total & 12774 & 1267 & 10 & 5106 & 284 & 6 \\
\hline
\end{tabular}


Table 5

Sumary of Survey Data

(percent of cars)

\begin{tabular}{|c|c|c|c|c|c|c|c|}
\hline . & Police & $\begin{array}{l}\text { Govern- } \\
\text { ment }^{\mathbf{a}}\end{array}$ & Utillty & Taxd & Rental & Business & $\begin{array}{l}\text { All } \\
\text { Sectors }\end{array}$ \\
\hline Needs only 2 seats & 3 & 26 & 29 & 3 & 11 & 14 & 17 \\
\hline $\begin{array}{l}\text { Needs a range of: } \\
\text { Less than } 80 \mathrm{~km}(50 \mathrm{mi}) \\
\text { Less than } 161 \mathrm{~km}(100 \mathrm{mi}) \\
\text { Less than } 241 \mathrm{~km}(150 \mathrm{mI})\end{array}$ & $\begin{array}{l}0 \\
1 \\
3\end{array}$ & $\begin{array}{r}3 \\
25 \\
32\end{array}$ & $\begin{array}{r}2 \\
34 \\
57\end{array}$ & $\begin{array}{r}0 \\
5 \\
39\end{array}$ & $\begin{array}{r}0 \\
33 \\
40\end{array}$ & $\begin{array}{r}0 \\
8 \\
18\end{array}$ & $\begin{array}{r}1 \\
16 \\
26\end{array}$ \\
\hline $\begin{array}{l}\text { Without options: } \\
\text { Alutomatic transmission } \\
\text { Power steering } \\
\text { Power brakes } \\
\text { Air conditioning }\end{array}$ & $\begin{array}{r}0 \\
0 \\
0 \\
19\end{array}$ & $\begin{array}{r}1 \\
5 \\
18 \\
49\end{array}$ & $\begin{array}{r}5 \\
30 \\
30 \\
57\end{array}$ & $\begin{array}{r}6 \\
6 \\
23 \\
49\end{array}$ & $\begin{array}{r}2 \\
9 \\
10 \\
2\end{array}$ & $\begin{array}{l}0 \\
1 \\
3 \\
1\end{array}$ & $\begin{array}{r}1 \\
6 \\
9 \\
18\end{array}$ \\
\hline $\begin{array}{l}\text { Avatlable for long refueling ( } 8 \mathrm{~h} \\
\text { at central location) }\end{array}$ & 20 & 49 & 51 & 25 & 18 & 20 & 28 \\
\hline $\begin{array}{l}\text { Not needing high performance } \\
\text { (Interstate highway capabilities) }\end{array}$ & 9 & 31 & 25 & 40 & 5 & 24 & 21 \\
\hline $\begin{array}{l}\text { Avaflable for long refueling and } \\
\text { not needing high performance }\end{array}$ & 4 & 11 & 15 & 9 & 3 & 11 & 10 \\
\hline
\end{tabular}

'State and local non-police.

physical attributes other than seating. The 17 percent figure therefore defines an "applicability rate" for a two-seat vehicle whose physical attributes are otherwise the same as, or superior to, those of othcr cars: It differs from an estimate of market penetration rate in that it does not take into account the effect of vehicle cost. From the data in Table 4, a 17 percent market share is estimated to represent 870,000 cars $(0.17$ $x 5,106,000$ ) in the fleet sectors covered by the survey. Assuming that these vehicles spend an average of 3 years in fleet service, ${ }^{9}$ this corresponds to a sales volume of 290,000 cars per year.

In judging which attributes are most restrictive of EC applicability, it is helpful to examine the attributes of currently avallable ECs. These are shown in Table 6, along with those of a late model conventional rar.10-12 The Dodge Omn1 was chosen for cumparlsun because $1 \mathrm{t}$ was assumed to be representative of the type of petrolcum-fueled car agalinst which ECs would compete in the mid-1980s, the earliest possible date for large-scale EC production. This is not to say that the attributes of either ECs or conventional cars will be static. On the contrary, it is reasonable to assume that the attributes of ECs will improve both in absolute terms and in comparison with those of conventional cars. The point of the present analysis is to show where improvement is most needed. 


\begin{tabular}{|c|c|c|c|}
\hline \multicolumn{4}{|c|}{$\begin{array}{c}\text { Table } 6 \\
\text { Present Status of Electric Car Attributes and } \\
\text { Likely Attributes of Mid-1980s Conventional Car }\end{array}$} \\
\hline & \multicolumn{2}{|c|}{ Electric } & \multirow{2}{*}{$\begin{array}{l}\text { Conventional } \\
\text { (1979 Dodge } \\
\text { Omni) }\end{array}$} \\
\hline & $\begin{array}{c}\text { EC } 1 \text { (EVA } \\
\text { Change-of-Pace) }\end{array}$ & $\begin{aligned} \text { EC } & 2 \text { (SCT } \\
\text { R-1 } & \text { Electric })\end{aligned}$ & \\
\hline $\begin{array}{l}\text { Primary targets: } \\
\text { Seating capacity } \\
\text { Range (SAE J227a,C) } \\
\text { Refuel time ( } 80 \% \text { discharge) } \\
\text { Availability of options: } \\
\text { Automatic transmission } \\
\text { Power steering } \\
\text { Power brakes } \\
\text { Air conditioning }\end{array}$ & $\begin{array}{c}4 \\
50 \mathrm{~km}(31 \mathrm{mi}) \\
8 \mathrm{~h} \\
\text { yes } \\
\text { no } \\
\text { no } \\
\text { no }\end{array}$ & $\begin{array}{c}2 \\
71 \mathrm{~km}(44 \mathrm{mi}) \\
8 \mathrm{~h} \\
\text { no } \\
\text { no } \\
\text { no } \\
\text { no }\end{array}$ & $\begin{array}{c}4 \\
500 \mathrm{~km}(300 \mathrm{~m} 1)^{\mathrm{a}} \\
0.1 \mathrm{~h} \\
\\
\text { yes } \\
\text { yes } \\
\text { yes } \\
\text { yes }\end{array}$ \\
\hline $\begin{array}{l}\text { Selected secondary targets: } \\
\text { Acceleration, } 0-48 \mathrm{~km} / \mathrm{h} \\
\text { Speed: Cruising } \\
\text { Maximum } \\
\text { Gradeability ( } 10 \% \text { grade) }\end{array}$ & $\begin{array}{l}11 \mathrm{~s} \\
71 \mathrm{~km} / \mathrm{h}(44 \mathrm{mph}) \\
90 \mathrm{~km} / \mathrm{h}(56 \mathrm{mph}) \\
24 \mathrm{~km} / \mathrm{h}(15 \mathrm{mph})\end{array}$ & $\begin{array}{l}10 \mathrm{~s} \\
71 \mathrm{~km} / \mathrm{h}(44 \mathrm{mph})> \\
97 \mathrm{~km} / \mathrm{h}(60 \mathrm{mph}) 1 \\
35 \mathrm{~km} / \mathrm{h}(22 \mathrm{mph})\end{array}$ & $\begin{array}{l}4 \mathrm{~s} \\
>89 \mathrm{~km} / \mathrm{h}(>55 \mathrm{mph}) \\
146 \mathrm{~km} / \mathrm{h}(91 \mathrm{mph}) \\
89 \mathrm{~km} / \mathrm{h}(55 \mathrm{mph})^{\mathrm{a}}\end{array}$ \\
\hline
\end{tabular}

From Table 5 and 6 , it appears that the applicability of EC 1 is most constrained by its range, in that one percent or less of the sample vehicles had range needs within EC 1 's expressed capability of $50 \mathrm{~km}$ (31 $\mathrm{mi})$. EC 2 is in the same situation with respect to range, but is also held in check by its lack of an automatic transmission. If these barriers were eliminated, the next obstacles to limit the applicability of the two ECs would likely be their lack of power steering and power brakes, although these factors are much less restrictive in certain market sectors. When examined singly, the least restrictive EC attributes appear to be their refueling characteristics and their inability to use interstate highways (this inability is deduced from the Table 6 data on acceleration, speed, and gradeability). This information is summarized in Table 7. Note that, aside from the possibility of a constraint arising from seating capacity, the conventional car appears to have unconstrained applicability.

A more conclusive way of estimating applicability rates is to compare a particular vehicle's full set of attributes with the needs of a particular respondent. An applicability rate can thus be found for each respondent. An applicability rate for each market sector can then be found by taking a vehicle-weighted average of the rates for the individual respondents. 


\begin{tabular}{lcc}
\hline & $\begin{array}{c}\text { Table } 7 \\
\text { Ranking of Applicability Constraints }\end{array}$ \\
\hline & $\begin{array}{c}\text { Maximum applicability percent } \\
\text { when constraints applied singly }\end{array}$ \\
\cline { 2 - 3 } \multicolumn{1}{c}{ Constraints } & EC 1 & EC 2 \\
\hline Range <80 km (<50 m1) & 1 & 1 \\
Manual transmission & -5 & 1 \\
No power steering & 9 & 6 \\
No power brakes & -5 & 17 \\
2-seat capacity & 18 & 18 \\
No air conditioning & 21 & 21 \\
Unable to use interstates & 28 & 28 \\
8-hour refueling & & \\
\hline
\end{tabular}

When this is done for EC 1 and EC 2, applicability rates of about one-tenth of one percent emerge. However, to date this has been done only under the pessimistic assumption that there is no correlation between the attributes needed for a particular vehicle mission. To illustrate, assume a fleet operator indicated that 10 percent of his or her cars need less than a $80 \mathrm{~km}$ ( $50 \mathrm{mi}$ ) range and that 20 percent need only two seats. The applicability estimates compiled to date have assumed no correlation between seating capacity needs and range needs. That is, assuming that one is evaluating an EC with a range of $80 \mathrm{~km}(50 \mathrm{mi})$ and two seats, the calculated applicability rate for the above respondent would be 2 percent $(0.1 \times 0.2=0.02)$. The true situation may be that there is high correlation between seating capacity needs and range needs, such that all of this respondent's cars that need only $80 \mathrm{~km}(50 \mathrm{mi})$ range also need only two seats. In that case, the applicability rate for this respondent would be 10 percent $(0.1 \times 1.0=0.1)$.

\section{SUMMARY}

If the EC is to play an important role in reducing petruleum consumption, it must obtain a significant share of the automobile market. Within the automobile market, the fleet market is an important segment because of its size, unique motivations, and attractiveness as an EC test market. A large number of vehicle attributes will ultimately determine the market penetration of ECs in the fleet market. This paper has attempted to illuminate the effect that some of the more quantifiable and projectable attributes can have on the market success of the EC.

The greatest constraints on the fleet market applicability of currently available ECs appear to be their range limitations and their lack of power options. Their least constraining attributes, among those examined, appear to be their need for lengthy recharging and their presumed inability to use interstate highways, but even these would limit ECs to a 
minority share of the fleet market. Comparison of all attributes of present ECs with the needs of sampled fleet operators, albeit under pessimistic assumptions, shows estimated EC applicability rates to be negligible.

\section{REFERENCES}

1. D. B. Shonka, Editor, Transportation Energy Conservation Data Book: Edition 3, Oak Ridge National Laboratory, Report No. ORNL-5493 Special, prepared for U.S. Department of Energy, February 1979.

2. MVMA Facts and Figures '79, Motor Vehicle Manufacturers Association.

3. Automotive Fleet, Volume 18, No. 6 (April 1979).

4. Electric \& Hybrid Vehicle Program, The Second Annual Report to Congress for Fiscal Year 1978, U.S. Department of Energy, Report No. DOE/CS-0068, January 1979.

5. The First Annual Report to Congress on the Implementation of Public Law 94-413, The Electric and Hybrid Vehicle Research, Development and Demonstration Act of 1976, U.S. Department of Energy, Report No. $\overline{\mathrm{DOE} / \mathrm{CS}-0002 / 1 \text {, December } 1977 .}$

6. Anton S. Morton, et al., Incentives and Acceptance of Electric, Hybrid, and Other Alternative Vehicles, Arthur D. Little, Inc., Report No. 80767, prepared for U.S. Department of Energy, November 1978.

7. Institutional Factors in Transportation Systems and Their Potential for Bias Toward Vehicles of Particular Characteristics, Transportation Systems Center (U.S. Department of Transportation), Report No. HCP/M1043-01, prepared for U.S. Department of Energy, February 1978.

8. Joseph R. Wagner, Fleet Operator Data Book (Summer 1977 Data), Vo1ume 1: National Data, Brookhaven National Laboratory Report No. BNL 50904, prepared for U.S. Department of Energy, Seprember 1979.

9. Ibid., p. 33 .

10. "Four New EVs Delivered to DOE," Electric Vehicle News, Volume 8, No. 3 (August 1979).

11. 1979 Gas M1leage Gu1de (Second Edition), U.S. Vepartment of Energy, Report No. DOE/CS-0024/5, January 1979.

12. Annamaria Losch, Editor, World Cars 1979, Herald Books, Pelham, N.Y., 1979. 


\section{APPENDIX: BOBIT QUESTIONNAIRE}

\section{LOCATION AND TYPE OF FLEET}

The questions on this page are not intended to identify specific respondents, but rather w111 be used to divide respondents into general groups. Al1 responses are considered confidential. With these things in mind, you would greatly assist us by placing a check mark next to your market sector and by recording your location and fleet type (owned or leased).

I. MARKET SECTOR:

State Government

Police

Non Police

Local Government

Police

Utility

Non Police

Taxi

Auto Rental

Business Fleet (25 vehicles or more)

Business Fleet (4-24 vehicles)

State:

City:

Management :

Percent of vehicles owned $=$ , leased $=$

\section{HISTORICAL INFORMATION}

In addition to knowing the composition of your fleet as it exists today, it is important for us to know how this composition has changed over the years to enable us to identify historical trends. Please indicate in the tables below (in absolute numbers) the purchases made for the fleet and the composition of the fleet for the years 1966 through 1976.

Table of Purchases

\begin{tabular}{l}
1966 Small Cars $\quad$ Mcdium Cars Large Cars \\
1967 \\
1968 \\
1969 \\
1970 \\
1971 \\
1972 \\
1973 \\
1974 \\
1975 \\
\hline
\end{tabular}


Table of Fleet Composition

\begin{tabular}{l}
1966 Small Cars $\quad$ Medium Cars \\
$\frac{1967}{1967}$ \\
\hline 1968 \\
\hline 1970 \\
$\frac{1971}{1972}$ \\
$\frac{1973}{1974}$ \\
\hline 1975 \\
\hline 1976
\end{tabular}

1. Rate the following criteria for your automobile purchases on a scale of 1 to 5,5 being the most important: (circle answer)

Purchase Price

Resale Value (as \% of original cost)

Maintenance Costs

Life-Cycle Cost

Reliability (day by day)

Running Lifetime

Tradition (1.e., past experience)

Gas Mileage

Other (specify)

$\begin{array}{lllll}1 & 2 & 3 & 4 & 5 \\ 1 & 2 & 3 & 4 & 5 \\ 1 & 2 & 3 & 4 & 5 \\ 1 & 2 & 3 & 4 & 5 \\ 1 & 2 & 3 & 4 & 5 \\ 1 & 2 & 3 & 4 & 5 \\ 1 & 2 & 3 & 4 & 5 \\ 1 & 2 & 3 & 4 & 5 \\ 1 & 2 & 3 & 4 & 5\end{array}$

NOTE: Please answer questions 2 through 10 in terms of each of the size categories defined in question 2 .

2. How many vehicles do you have in the following categories:

Passenger Car - Small : (e.g. Gremlin, Vega, Mustang II, and others weighing less than 3050 lbs.)

- Medium (e.g. Granada, Maverick, Aspen, Volare, Hornet, Skylark 6, Nova, Omega, Ventura, Pacer and others weighing 3050-3500 1bs.)

- Large (e.g. Skylark 8, Monaco, Fury, Matador, Chevelle, Century, Cutlass, LeMans, LTD II, Cougar, and others weighing more than 3500 lbs.)

Light Truck - Pick Up

- Van 
3. Which of the following power options would you typically (more than half the time) specify for your vehicles: (circle answer)

Small Car Medium Car Large Car Light Truck

- Automatic Transmission
- Power Steering
- Power Brakes
- Air Conditioning
- Radio
- Trailer Towing Options
- Other (specify)

$\begin{array}{llllllll}\text { Yes } & \text { No } & \text { Yes } & \text { No } & \text { Yes } & \text { No } & \text { Yes } & \text { No } \\ \text { Yes } & \text { No } & \text { Yes } & \text { No } & \text { Yes } & \text { No } & \text { Yes } & \text { No } \\ \text { Yes } & \text { No } & \text { Yes } & \text { No } & \text { Yes } & \text { No } & \text { Yes } & \text { No } \\ \text { Yes } & \text { No } & \text { Yes } & \text { No } & \text { Yes } & \text { No } & \text { Yes } & \text { No } \\ \text { Yes No } & \text { Yes } & \text { No } & \text { Yes } & \text { No } & \text { Yes } & \text { No } \\ \text { Yes No } & \text { Yes } & \text { No } & \text { Yes } & \text { No } & \text { Yes } & \text { No } \\ \text { Yes No } & \text { Yes } & \text { No } & \text { Yes } & \text { No } & \text { Yes } & \text { No }\end{array}$

4. Is the present availability of diesel fuel sufficient for you to consider using diesel power, if it were avallable as an option in the models you currently use? (circle answer)

$\begin{array}{lll}\text { Small Car } & \text { Yes } & \text { No } \\ \text { Medium Car } & \text { Yes } & \text { No } \\ \text { Large Car } & \text { Ycs } & \text { No } \\ \text { Light Truck } & \text { Yes } & \text { No }\end{array}$

5. NOTE: As of now electric vehicles have a limited cruising range, after which an eight hour recharge period is typlcally required. The purpose of this question is to determine on the basis driving range only, the sultability of the electric car tn automobile. fleets.

On any given day a vehicle selected for your fleet must be capable of driving at least: (circle answer)
Small Car
(a) 0-50 miles
(b) 50-100 miles
(c) 100-150 miles
(d) more than 150 miles
Medium Car
(a) 0-50 miles
(c) 100-150 miles
(b) 50-100 miles
(a) 0-50 miles
(d) more than 150 miles
Large Car
(c) 100-150 miles
(b) 50-100 miles
(d) more than 150 miles
Light Truck
(a) 0-50 miles
(b) 50-100 miles
(c) 100-150 miles
(d) more than 150 miles

6. What percentage of your cars sit idle for eight consecutive hours or more at a central location, during every 24 hour period (for each size category)?
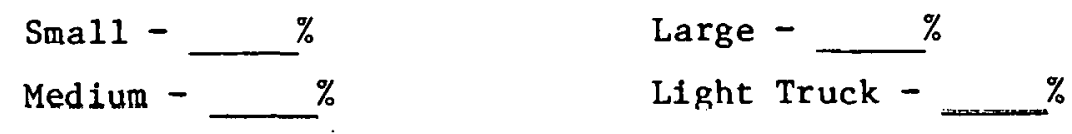
7. What percentage of your cars, within each size category, do not need the ability to accelerate and cruise on interstate highways? (Fill 1 number)
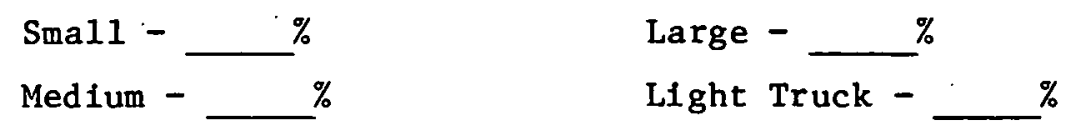

8. What percentage of your cars have both characteristics (1.e., do not need interstate travel capabilities and sit for 8 hours or more at a central location), for each size category?

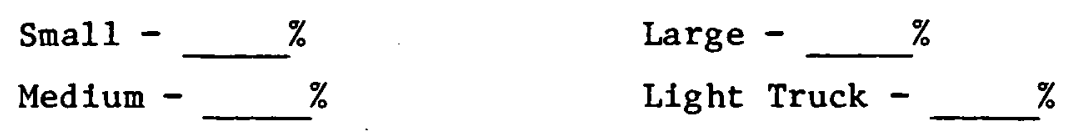

9. What percentage of your fleet would be adequately served with a vehicle capable of seating only two (2) passengers?

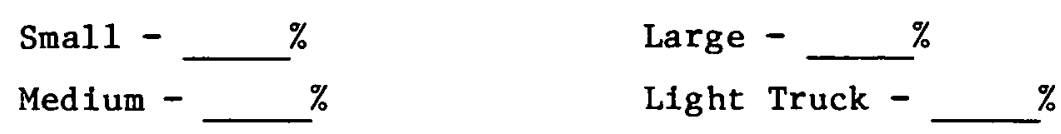

10. What is the minimum number of adult passengers that you would expect your vehicles to be able to carry?

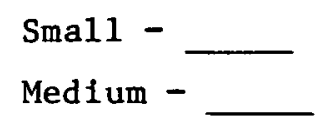

$$
\begin{aligned}
& \text { Large - } \\
& \text { Light Truck - }
\end{aligned}
$$

11. What is the estimated number of miles driven per year by your average vehicle?

\section{Answer -}

12. How do you select the engine size you order for your vehicles? (e.g., always take standard equipment, always V8 engines, etc.)

13. How do you decide to dispose of a vehicle? (e.g., accumulated mileage, vehicle age, etc.) (please specify an amount)

14. Are your purchases or leases restricted at all by any special contractual arrangements? (circle answer) Yes No

If $s n$, hnw? 